\title{
EFFECTS OF GROWTH HABITS OF LEGUMES ON WEED POPULATION IN GRASS/LEGUME MIXED SWARDS
}

\author{
EFECTOS DE LOS HÁBITOS DE CRECIMIENTO DE LEGUMINOSAS EN LA POBLACIÓN \\ DE MALAS HIERBAS EN MEZCLAS PRATENSES GRAMÍNEAS/LEGUMINOSAS
}

Jolaosho, A.O., U.Y. Anele, O.M. Arigbede, J.A. Olanite and O.S. Onifade

Department of Pasture and Range Management. College of Animal Science and Livestock Production. University of Agriculture. P.M.B. 2240 Abeokuta. Nigeria. ajolaosho@yahoo.com

\section{AdDitionAL KEYWORDS}

Stylosanthes hamata. Tephrosia bracteolata. Competition for resources.

\section{SUMMARY}

Grass-legume swards form the basis of many productive pasture systems. A study was carried out to evaluate their ability to smother weeds. A total of twelve treatments consisting of grass/ legume mixed swards were planted in July, 2004. Soil analysis of the site was carried out prior to and after the study. Some agronomic data like plant height, leaf number and population of weeds found in the plots were recorded using a meter square quadrat. There was a slight increase in the nitrogen content of the soil in 2005 after the study. The weed populations were highest during the first three weeks after planting. The weed population reduced drastically with increasing week. There were significant differences $(p<0.05)$ in the population of the weeds in the mixed sward during the 2 year duration of this study. Stylosanthes hamata recorded higher weed populations during the first year while a higher weeds population was recorded in the plots of Tephrosia bracteolata during the second year.

\section{RESUMEN}

Las praderas mixtas de gramíneas y leguminosas forman la base de muchos sistemas productivos de pastoreo. Se realizó un estudio para evaluar su capacidad para sofocar a las malas hierbas. En julio de 2004 se plantaron un total de 12 tratamientos a base de mezclas de gramíneas leguminosas. Se realizaron análisis del suelo anteriores y posteriores al estudio. Usando un cuadrado de $1 \mathrm{~m}^{2}$ se registraron datos agronómicos

Recibido: 2-3-07. Aceptado: 6-3-07.

\section{Palabras clave adicionales}

Stylosanthes hamata. Tephrosia bracteolata. Competencia por los recursos.

como altura de las plantas, número de hojas y población de malas hierbas presentes en las parcelas experimentales. Se registró un ligero incremento en el contenido de $\mathrm{N}$ del suelo en 2005 , después del estudio. Las poblaciones de malas hierbas fueron mayores durante las tres primeras semanas después de la siembra. La población de malas hierbas se redujo drásticamente cada semana. Hubo diferencias significativas $(p<0,05)$ en la población de malas hierbas de las praderas mixtas durante los dos años de duración de este estudio. Stylosanthes hamata registró la mayor población de malas hierbas durante el primer año mientras que la mayor población de malas hierbas fue registrada en las parcelas de Tephrosia bracteolata durante el segundo año.

\section{INTRODUCTION}

Legumes in grass/legume mixed swards are noted to play key roles in provision of year-round high quality forages for the ruminant animals as well as improving the soil nutrient status. Apart from fixing nitrogen which can be utilized by grasses, the integration of legumes can also offset the need for yearly top dressing of sole grass pasture with nitrogen fertilizer. Mixtures are also more productive during dry season and have a higher nutritional value than grass alone (Roberts, 1994). Both grasses and legumes can be used for pasture. 
Legume-grass combinations will usually result in better forage production and animal performance than will a single species grown alone. A grass/legume mixture is also better for pastures than a pure legume because it increases soil and water conservation, enhances weed control, reduces risk of total stand loss due to thinning of legume stands, bloat protection for animals grazing exclusively legumes, and increases longevity and production of the pasture (Casler and Walgenbach, 1990). Meanwhile, maintaining tropical legumes as a pasture component over time has been a major challenge because most of the highly productive tropical grasses are tall growing and very aggressive.

Therefore, this study aims to determine the effects of the growth rate of some legumes in grass/legume mixtures and their ability to suppress weed growth as weed infestation is a major concern in the management of grass-legume mixtures especially at the early stages of establishment (Peters and Linscott, 1988). Efforts have therefore been intensified to develop legumes that are well compatible with the existing grasses so as to enhance the productive life of the grass-legume mixtures that are developed from them.

\section{MATERIALSANDMETHODS}

The experiment was conducted at the University of Agriculture Teaching and Research farm, Alabata Abeokuta beginning from July 2004 - October 2005. A total area of $378 \mathrm{~m}^{2}$ used for the experiment was divided into three replicates with each replicate subdivided into twelve equal plots of $3 \mathrm{~m} \times 3 \mathrm{~m}$ each after ploughing and stumping. The experiment was laid out in a Completely Randomized design with three replicates. A total of fourteen treatments, consisting twelve grass-legume mixtures (two legumes and six grasses), and two pure legumes pasture. The legumes used were T. bracteolata (annual) and S. hamata cv Verano

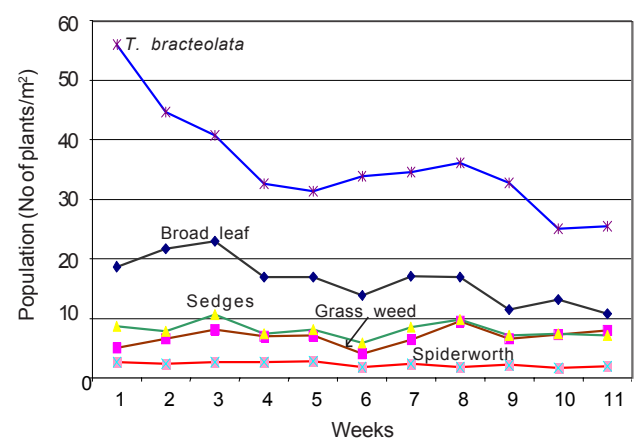

Figure 1. The effect of week on the population $\mathrm{T}$. bracteolata and the weeds in 2004. (Efecto del tiempo sobre la población de $T$. bracteolata y malas hierbas en 2004).

(perennial) while the six grasses were Brachiaria ruziziensis, B. decumbens, Andropogon tectorum, Pennisetum purpureum, Panicum maximum cv Nchitsi and Digitaria smutsii. The grasses were planted in rows spaced $1 \mathrm{~m}$ apart with the legumes drilled between the rows at the spacing of 50 $\mathrm{cm}$. Plant heights, leaf number per plant, number of stands per $\mathrm{m}^{2}$ and weed pressure were counted weekly using $1 \mathrm{~m}^{2}$ quadrat. The dry matter (DM) yield of the forages was estimated after the sixth and twelfth WAP. Data collected were subjected to one - way analysis of variance (ANOVA) as

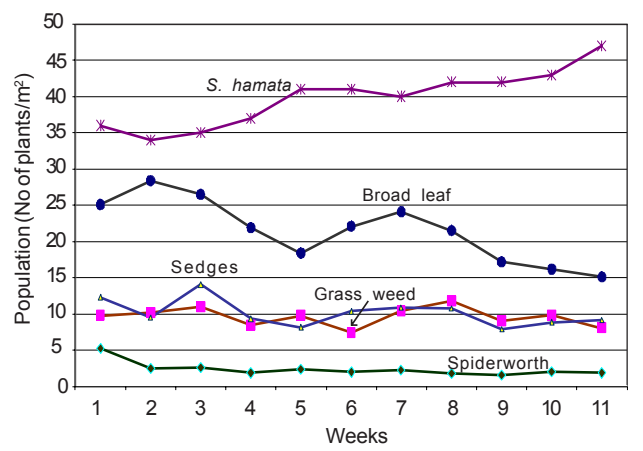

Figure 2. The effect of week on the population of S. hamata and the weeds in 2004. (Efecto del tiempo sobre la población de $S$. hamata y malas hierbas en 2004). 


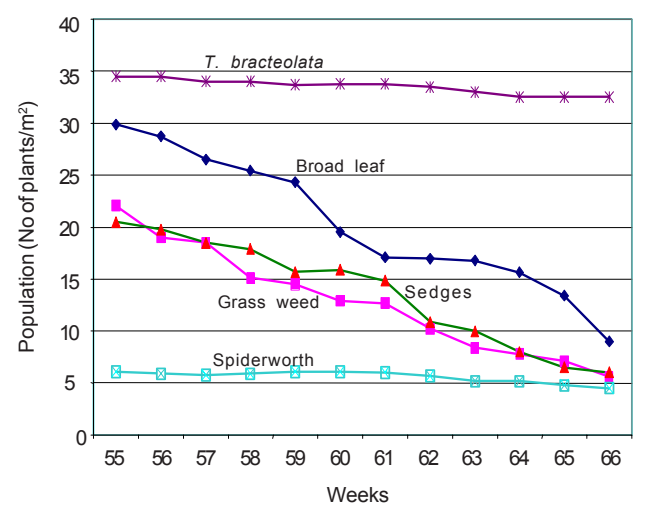

Figure 3. The effect of week on the population $\mathrm{T}$. bracteolata and the weeds in 2005. (Efecto del tiempo sobre la población de $T$. bracteolata y malas hierbas en 2005).

described by Wahua (1999). The mean weed pressure (weed number $/ \mathrm{m}^{2}$ ) and differences in legume growth rate were evaluated using T-test paired sample statistics and separated by Duncan Multiple Range Test (DMRT) (Duncan, 1955).

\section{RESULTSANDDISCUSSION}

$T$. bracteolata monoculture and $T$. bracteolata/grass mixtures recorded higher plant population during the first year which

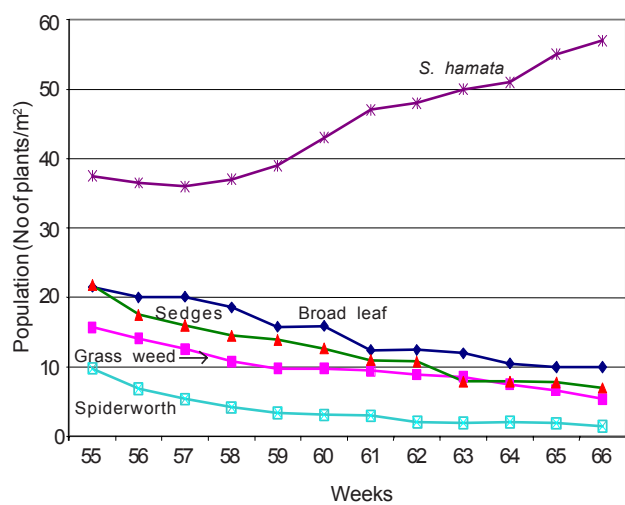

Figure 4. The effect of week on the population S. hamata and the weeds in 2005. (Efecto del tiempo sobre la población de $S$. hamata y malas hierbas en 2005) was significantly higher $(\mathrm{p}<0.05)$ than that recorded for $S$. hamata as shown in figures 1 and 2. The reverse was the case in the second year with $S$. hamata recording higher $(p<0.05)$ population than T. bracteolate (figures 3 y 4). The population of T. bracteolata decreased with increasing week due probably to intra-plant competition and the approaching dry season contrary to the gradual increase in the population of $S$. hamata as a result of its extended growth and ability to withstand drought (Skerman et al., 1998). The steady increase in its height and branches as the plant matured resulted in decreased weed population at the eleventh week.

The weed population was significantly higher $(\mathrm{p}<0.05)$ in all the plots of $S$. hamata than in T. bracteolata plots during the first year. Weed population was significantly higher in the mixed plot of $T$. bracteolata/B. ruziziensis, which was due to poor establishment of the grass as it was planted late as replacement after the initial grass (Chloris gayana) failed to germinate. Weed population in $S$. hamata plots was generally higher $(\mathrm{p}<0.05)$ in the sole plot than in the mixed plots where it was planted with the grasses. The lower weed population in all the plots of T. bracteolata in 2004 might be as a result of the ability of this annual legume to grow quickly and form canopy which will produce a shading effect on the weed seedlings unlike $S$. hamata, a perennial legume, that is relatively slower in growth and takes time to establish properly (Babayemi, 2002). This leads to delay in soil coverage and provides advantage for weeds in the plots to grow more. The significantly $(\mathrm{p}<0.05)$ higher population and greater height of $T$. bracteolata compared to $S$. hamata also support this observation which definitely will have some suppressing effects on the weeds (Robert, 1994).

The higher weed population observed in the monoculture of $S$. hamata could be as a result its slow - growing and semi - erect 
growth habit, contrary to the lower weed population recorded in the mixed plots with the grasses, where the aggressive and fast growing grasses may have contributed in reducing the weed populations (Skerman et al., 1998).

\section{REFERENCES}

Babayemi, O.T. 2002. Sustainability of Tephrosia bracteolata as forage for the West African Dwarf goats in Nigeria. Product. $7^{\text {th }}$ Annual Conference Animal Science Association of Nigeria (ASAN), Sept 16-19, 2002. University of Agriculture, Abeokuta Nigeria. p. 221- 222.

Casler, M.D. and R.P. Walgenbach. 1990. Ground cover potential of forage grass cultivars mixed with alfalfa at divergent locations. Crop Sci., 30 : 825-831.

Duncan, D.B. 1955. Multiple range and multiple Ftests. Biometrics, 11: 1-42.

Peters, E.J. and D.L. Linscott. 1988. Weeds and
It can be concluded from the study that annual legume like $T$. bracteolata can be utilized as a major component in the supply of early feed resource to livestock. Legumes can also can be effectively utilized in suppressing the deleterious effect of weeds.

weed control. In: A.A. Hanson (ed.). Alfalfa and alfalfa improvement. Agronomy, 29: 705-735.

Roberts, C. 1994. Plant growth and forage quality. In: 1994 Missouri Grazing Manual (M157). University of Missouri. Forage Systems Research Center.

Skerman, P.J., D.G. Carmeron and F. Riveros. 1998. Tropical forage legumes. FAO Publications. Databases: http://www.fao/ag/AGP/AGPC/ doc/Gbase/data/pf 000065.htm

Wahua, T.A.T. 1999. Applied statistics for scientific studies, Ibadan, Afrika-Link Press. p. $130-134$ 